\title{
Uniformed Services Pension Amendment Acts in Poland as Part of State Politics of Memory
}

\section{Introduction}

Post-communist countries in the transition period carry a burden of dealing with the past. By politics of memory, states strive to shape common awareness about past events, and thus try to maintain their collective memory through various mechanisms. To this end, they can decide to withdraw certain privileges for persons associated with the previous system, an example of which is the reduction of retirement benefits for a specific group associated with the former system. Such mechanisms were introduced in Poland under the Uniformed Services Pensions Amendment Acts of $2009^{2}$ and $2016^{3}$.

This paper examines sanctions taken against former officers of the security service of the Polish People's Republic (Polish: Polska Rzeczpospolita Ludowa, PRL), in particular the decrease of their retirement and disability benefits, and assesses these sanctions from the perspective of transitional justice and the implementation of state politics of memory. The aim is to prove that reducing pensions by means of the Uniformed Services Pensions Amendment Acts of 2009 and 2016 is part of the legal institutionalization of memory. While the 2009 Amendment had a somewhat retrospective goal,

ORCID number: 0000-0002-7554-5692. E-mail: mateusz.grabarczyk@amu.edu.pl

2 The Act of 23 January 2009 amending the Act on Retirement Provision of Professional Soldiers and Their Families, and the Act on Retirement Provision of Officers of the Police, the Internal Security Agency, the Foreign Intelligence Agency, the Military Counterintelligence Service, the Military Intelligence Service, the Central Anti-Corruption Bureau, the Border Guard, the Office Protection of the Government, the State Fire Service and the Prison Service and Their Families (Polish title: Ustawa z 23.01.2009 r. o zmianie ustawy o zaopatrzeniu emerytalnym żołnierzy zawodowych oraz ich rodzin oraz ustawy o zaopatrzeniu emerytalnym funkcjonariuszy Policji, Agencji Bezpieczeństwa Wewnętrznego, Agencji Wywiadu, Służby Kontrwywiadu Wojskowego, Służby Wywiadu Wojskowego, Centralnego Biura Antykorupcyjnego, Straży Granicznej, Biura Ochrony Rządu, Państwowej Straży Pożarnej i Służby Więziennej oraz ich rodzin, Dz. U. z 2009 r. Nr 24, poz. 145), hereinafter the "2009 Uniformed Services Pensions Amendment Act" or the "2009 Amendment".

3 The Act of 16 December 2016 Amending the Act on the Retirement Provision of Officers of the Police, the Internal Security Agency, the Foreign Intelligence Agency, the Military Counterintelligence Service, the Military Intelligence Service, the Central Anti-Corruption Bureau, the Border Guard, the Government Protection Bureau, the State Fire Service and the Prison Service and Their Families (Polish title: Ustawa z 16.12.2016 r. o zmianie ustawy o zaopatrzeniu emerytalnym funkcjonariuszy Policji, Agencji Bezpieczeństwa Wewnętrznego, Agencji Wywiadu, Służby Kontrwywiadu Wojskowego, Służby Wywiadu Wojskowego, Centralnego Biura Antykorupcyjnego, Straży Granicznej, Biura Ochrony Rządu, Państwowej Straży Pożarnej i Służby Więziennej oraz ich rodzin, Dz. U. z 2016 r. poz. 2270), hereinafter the "2016 Uniformed Services Pensions Amendment Act" or the "2016 Amendment". 
the Act of 2016 is primarily a prospective element of politics of memory, aimed at the authorities shaping a specific narrative about past events by explicitly condemning the previous system and all people associated with it in any way.

\section{Politics of memory (as a part of transitional justice)}

Transitional justice can be considered both sui generis and complex ${ }^{4}$. As Michał Krotoszyński indicated, this multifaceted, self-complimentary phenomenon is comprised of three main aspects: 1) legal and extra-legal mechanisms implemented to account for the past and fulfil other purposes of transitional justice; 2) the conception of justice in the context of transitional periods; and 3) political decisions to use transitional justice mechanisms which are based both on accepted formulas of justice and on conditions outside of the domain of ethics ${ }^{5}$. This paper focuses on the last aspect. From this perspective, the mechanisms of transitional justice are an expression of specific political decisions. In this context, transitional justice can be understood as decisions to use certain mechanisms of dealing with the past $^{6}$. Jon Elster distinguishes two types of said decisions: 1) substantive, and 2) procedural ones:

The decisions I have identified (...) are substantive decisions that new regimes may face: whom to try, sanction, and compensate; and how to try, sanction, and compensate them. In addition, transitional justice almost invariably involves procedural decisions that deviate from the standards of "pure legal justice"

In other words, the author distinguished and examined: 1) substantive decisions relating to a range of questions, answers, and definitions of wrongdoings, especially questions concerning perpetrators, victims, and ways of dealing with them, and 2) procedural decisions relating to implementation of substantive decisions by creating a process framework to achieve goals determined by these substantive decisions ${ }^{8}$. In this case the goal is to shape common awareness and build a specific narrative about the past in order to integrate society. The means used in the processes include taking privileges away from persons who supported the system of unjust power, changing street names or establishing museums. The politics of memory shaped in this fashion combines institutional, symbolic and subjective dimensions, which results in an attempt to explain

\footnotetext{
${ }_{4}$ For a comprehensive analysis of transitional justice, see e.g.: R. Teitel, Transitional Justice, New York 2000; J. Elster, Closing the Books: Transitional Justice in Historical Perspective, Cambridge 2004; R. Teitel, Transitional Justice Genealogy, "Harvard Human Rights Journal” 2003/16, pp. 69-94; K. Wigura, J. Kuisz, W. Sadurski (eds.) Trudne rozliczenia z przeszłościa [Eng. Difficult Reckoning with the Past], Vol. I-II, Warszawa 2018; M.S. Williams, R. Nagy, J. Elster (eds.), Transitional Justice, New York-London 2012; N.J. Kritz, (ed.), Transitional Justice: How Emerging Democracies Reckon with Former Regimes, Vol. I-III, Washington 1995.

5 M. Krotoszyński, Modele sprawiedliwości tranzycyjnej [Eng. Models of Transitional Justice], Poznań 2017, pp. 58-60. For more on the first aspect see e.g.: M.M. Kaminski, M. Nalepa, B. O'Neill, Normative and Strategic Aspects of Transitional Justice, "The Journal of Conflict Resolution" 2006/3, pp. 295-302. For transitional justice understood as "the conception of justice associated with periods of political change" see: R. Teitel, Transitional Justice Genealogy..., p. 69. For transitional justice as a political decision see: J. Elser, Closing..., pp. 116-135.

M. Krotoszyński, Modele..., pp. 58-59.

7 J. Elster, Closing..., p. 129. The author believes "pure legal justice" to be characterized by four features: 1) unambiguousness of legal provisions; 2) "insulation" of the judiciary from other governments branches; 3) judges and jurors who interpret the law in an unbiased manner, and 4) adherence to the principles of due process by legal justice (see: J. Elser, Closing..., pp. 86-87). Procedural decisions that deviate from the above-mentioned standards include: retroactive legislation, arbitrary selection of indictees, extending or canceling periods of limitation (see: J. Elster, Closing..., pp. 129-135).

8 See: J. Elser, Closing..., pp. 116-135.
} 
the past, punish the perpetrators of violations, identify victims, and pass on the heritage shaped in this way to subsequent generations, ensuring the resulting construction of a new, democratic order based on the rule of law ${ }^{9}$. In view of the multitude and diversity of interpretations of the past, finding one common vision of the past within collective memory is almost impossible ${ }^{10}$, nevertheless countries strive for it.

Collective memory forged this way is part of politics of memory as one of the possible mechanisms of the historical clarification mode ${ }^{11}$. These mechanisms are used to disclose information about the nature of the previous system (or the course of the armed conflict), as well as the role of an individual within them. In this model sanctions are not significant, although they can be applied to people who refuse to participate in the process of clarification or those who actively seek to "distort" the image of the past. These actions can have an individual or collective dimension. The former dimension serves to disclose the behaviour of individuals in the pre-transition period (vetting, disclosure of files). The latter one creates a holistic picture of the past (truth finding), so their goal is to create a complete description of the period, and individual cases are only examples of the described trends (truth commissions, remembrance institutes).

In the former Eastern bloc countries (including Poland) there is an excess of history. An enormous number of documents created by the former regimes is kept in archives to this day. Yet, there are of dubious and unreliable origins. Therefore, instead of using them to create as objective a view of the past as possible, the states provide access to the archives (individual clarification) ${ }^{12}$. Thus, access to the files becomes an equivalent of access to history. It seems that this is conducive to the instrumentalization of memory policy, because lack of an official image of history (which is exceptionally difficult to establish due to the complexity of historical processes) facilitates the use of some elements of history for political purposes.

Historical clarification mechanisms and politics of memory play an extraordinary role in obtaining knowledge about the past and in making state institutions officially acknowledge that given events took place. Moreover, they send a message to victims and their families: an official adoption of their version of history by the state can be considered a confirmation of their arguments. Those mechanisms also enable the construction of an official historical narrative about past events, which to some extent also affects the construction of a specific identity of a given national community.

Politics of memory, in fact, does not speak about history, but about a certain interpretation of it. History is an objective ${ }^{13}$ study of past events considered together, especially events during a period, in a country, or related to a topic, which events make up a certain sequence. In turn, memory is more subjective, because it is not a faithful representation of history, due to its recall from the perspective of the present ${ }^{14}$.

9 E. Jelin, Public Memorialization in Perspective: Truth, Justice and Memory of Past Repression in the Southern Cone of South America, "The International Journal of Transitional Justice" 2007/1, p. 138.

10 E. Jelin, Public..., p. 140.

11 See: M. Krotoszyński, The Transitional Justice Models and the Justifications of Means of Dealing with the Past, "Oñati Socio-legal Series” 2016/3, pp. 592-594. See also: M. Krotoszyński, Modele..., pp. 118-141.

12 See: A. Ross, Truth and consequences in Guatemala, "GeoJournal" 2004/1, pp. 73-79; S. Rumin, Gathering and Managing Information in Vetting Processes, in: A. Mayer-Rieckh, P. de Greiff (eds.), Justice as Prevention. Vetting Public Employees in Transitional Societies, New York 2007, pp. 402-447; R. Teitel, Transitional Justice ..., pp. 69-94.

13 For more about objectivity and subjectivity of history see e.g.: Ch. Blake, Can History Be Objective?, "Mind" 1955/64, pp. 61-78; V. Hinshaw, The Objectivity of History, "Philosophy of Science" 1958/1, pp. 51-58; M. Bevir, Objectivity in History, "History and Theory" 1994/3, pp. 328-344.

14 See: D.L. Schacter, The Seven Sins of Memory: How the Mind Forgets and Remembers, Warsaw 2003. 
Politics of memory aims to build a certain collective memory of the past. Collective memory is an idea of the past of a given group developed by individuals on the basis of information from various sources, each piece of information being selected and transformed in accordance with the cultural standards and beliefs of the individual. These standards are a social product, ergo are common to members of a given community, which leads to the unification of perceptions of the past. Collective memory is not static, but variable and dynamic, which makes it a field of constant encounters and clashes ${ }^{15}$.

Collective memory gains importance particularly during the post-transitional period. In post-authoritarian or post-conflict countries, a political struggle around the significance of what happened and memory as such begins. As Elizabeth Jelin indicates:

After periods of high political conflict and repression or state terrorism, there is an active political struggle around meaning; the meaning of what went on and the meaning of memory itself. In this arena, the struggle is not one of memory against oblivion or silence, but rather between opposing memories, each of them with its own silences and voids ${ }^{16}$.

This is important because of the role of memory in building the identity of both the individual and the community. What we remember determines who we are, and who we are determines what we want to remember ${ }^{17}$.

In line with the above, politics of memory (or political history) can be defined as all public authorities' activities that aim to shape a specific narrative about the past. These include historical clarification mechanisms, especially collective ones, such as administrative sanctions ${ }^{18}$, an example of which is the mechanism for reducing pensions of specific groups.

\section{Transitional justice in Poland after $1989^{19}$}

To use Samuel Huntington's terminology, Poland we have experienced an endogenous transition (i.e. the transition without the influence of foreign countries) in the form of transplacement ${ }^{20}$. It arose as a result of the Roundtable Agreement between representatives of the undemocratic regime and the opposition (Solidarity trade union). The results of the agreement were of a momentous importance to the future political developments and final abolition of communism in Poland: in 1989 partially free elections were held and the first Solidarity government led by PM Tadeusz Mazowiecki was established. Thus, the process of decommunization began. This term can be understood

15 B. Szacka, Czas przeszty: pamięć - mit [Eng. Past Time: Memory, Myth], Warszawa 2006, pp. 32-46.

16 E. Jelin, Public..., p. 140.

17 See: A. Wolff-Powęska, Pamięć - brzemię i uwolnienie. Niemcy wobec nazistowskiej przeszłości (1945-2010) [Eng. Memory As Burden and Liberation: Germans and Their Nazi Past (1945-2010)], Poznań 2010.

18 In this text, I understand sanctions as any negative actions against an individual, including deprivation of privileges. See below, section 4.

19 More information and analysis about the Polish transition after 1989 can be found in e.g.: B. Banaszkiewicz, Rozrachunek z przeszłościa komunistyczna w polskim ustawodawstwie i orzecznictwie Trybunału Konstytucyjnego [Eng. Reckoning with Communist Past in Polish Legislation and Judgments of the Constitutional Tribunal], "Ius et Lex" 2003/1, pp. 441-486; M. Safjan, Transitional Justice: The Polish Example, the Case of Lustration, "European Journal of Legal Studies" 2007/2, pp. 235-253; A. Czarnota, The Politics of the Lustration Law in Poland, 1989-2006, in: A. Mayer-Rieckh, P. de Greiff (eds.), Justice..., pp. 222-258; M. Krotoszyński, Modele ..., pp. 113-118, 139-142; A. Czarnota, Lustration, Decommunization and the Rule of Law, "Hague Journal on the Rule of Law" 2009/1, pp. 307-336; K. Wigura, J. Kuisz, W. Sadurski (eds.) Trudne rozliczenia z przeszłościa, Tom II: Polska w Perspektywie Europy Środkowo-Wschodniej [Eng. Difficult Settlements with the Past, Vol II: Poland in the Perspective of Central and Eastern Europe], Vol. II, Warszawa 2018.

20 S. Huntington, The Third Wave: Democratization in the Late Twentieth Century, Warsaw 2009, pp. 166. 
in two ways. Firstly, it may be seen as the transition from communism towards democracy, a process which consists in the elimination of legislation, institutions, methods, strategies, governance structures and personnel of the previous regime ${ }^{21}$. Secondly, it may be perceived as the process of the imposition of administrative sanctions to those associated with the communist system.

The negotiated nature of the transition had some implications. Although it did not imply legal restrictions on the prosecution of human rights violations using criminal instruments, de facto the complicated legal status (prescription of crimes ${ }^{22}$ ) and evidence problems meant that the actual number of proceedings was moderate. In the years 2000-2020 the Institute of National Remembrance - Commission for the Prosecution of Crimes against the Polish Nation (Polish: Instytut Pamięci Narodowej-Komisja Ścigania Zbrodni przeciwko Narodowi Polskiemu, IPN) initiated 370 criminal trials against 558 people. Prosecutions initiated by IPN led to the conviction of 162 people 39 were acquitted and 88 died during trial ${ }^{23}$. In addition " 56 cases were discontinued due to amnesty and 162 others due to expiration of the limitation periods" ${ }^{24}$.

Instead, many mechanisms of historical clarification have been used, such as the creation of a permanent remembrance institute (IPN), reform of various institutions, vetting, truth trials, commemorative acts, and many symbolic actions, such as changing street names, removing monuments, erecting new ones, building museums, establishing memorial days, etc. A significant role was played by dispersed sanctions ${ }^{25}$ imposed due to the publication of information about persons who cooperated with the communist secret services ${ }^{26}$. Thus, after the Polish 1989 transition, mechanisms belonging both to the historical clarification model and to the retribution model were used.

The problem of dealing with the past seems timely in Poland, as new initiatives are still being undertaken to condemn the communist period and cut off from it. Recent ones include removing communist symbols from public space, extending the scope of vetting, and the reduction of pensions of former communist security service officers ${ }^{27}$.

\section{Reappointment process: institutional re-establishment}

In the retribution model ${ }^{28}$, sanctions are imposed on individuals who, in the pretransition period, committed acts that are negatively assessed in the new political reality. The sanctions can be perceived sensu largo, that is, as anything onerous directed against the individual, which also includes the loss of some privilege. In this case, apart from the classic criminal sanctions imposed in criminal proceedings, administrative

21 A. Severin, Measures to dismantle the heritage of former communist totalitarian systems, Doc. 7568, Report for Council of Europe's Parliamentary Assembly's Committee on Legal Affairs and Human Rights, 1996.

22 It should be noted that the 1989 Amnesty Act also partly contributed to this issue. See: The Act of 7 December 1989 on the Amnesty (Polish title: Ustawa z 7.12.1989 r. o amnestii, Dz. U. z 1989 r. Nr 64, poz. 390).

23 M. Nalepa, M. Krotoszyński, Poland, in: L. Stan, N. Nedelsky (eds.), Encyclopedia of Transitional Justice, Vol. 2 , $2^{\text {nd }}$ ed., Cambridge 2020 (forthcoming).

24 M. Nalepa, M. Krotoszyński, Poland (forthcoming).

25 Understood as sanctions of disapproval on the part of society, including condemnation, see: S. Wronkowska, Z. Ziembiński, Zarys teorii prawa [Eng. Introduction to Legal Theory], Poznań 2001, pp. 43 and 198; see also: L. Nowak, Power and Civil Society: Toward a Dynamic Theory of Real Socialism, New York 1991, p. 43.

26 M. Kowalczyk, Polska polityka historyczna w ustawach dekomunizacyjnych i dezubekizacyjnych [Eng. Politics of Memory in Polish Decommunization and Vetting Law], "Sensus Historiae" 2019/3, p. 40.

27 See: M. Krotoszyński, Transitional Justice and the Constitutional Crisis: The Case of Poland (2015-2019), "Archiwum Filozofii Prawa i Filozofii Społecznej” 2019/3, pp. 22-39.

28 M. Krotoszyński, The Transitional Justice Models..., pp. 589-592; M. Krotoszyński, Modele..., pp. 77-118. 
sanctions are also used. These include deprivation of passive suffrage, deprivation of a public position, prohibition of exercising certain public functions or, finally, reduction of retirement pension.

The first vetting procedure ${ }^{29}$ was applied to officers of the notorious communist secret service (Polish: Stużba Bezpieczeństwa, $\mathrm{SB}^{30}$ ). Shortly after the transition, the SB was abolished and a new Office of State Protection (Polish: Urzad Ochrony Państwa, UOP) was established. Under the UOP Act ${ }^{31}$, former SB officers and militia officers who had previously worked in the SB were, by operation of law, dismissed from service. Such persons, pursuant to a regulation of the Council of Ministers issued on the basis of the Act, could be re-employed in the UOP, the police, the Ministry of Home Affairs or a unit subordinate to the Ministry after obtaining a positive opinion from the selection committee, which consisted of representatives of the state, political parties and public organizations $\mathrm{s}^{32}$.

This vetting procedure was an example of a reappointment process: the public institution in question had been disbanded (SB), a new institution had been established (UOP) and there was a general competition for all posts. This kind of process constitutes a profound intervention both on individual and organizational level ${ }^{33}$. All SB officers were dismissed from the service and forced to reapply to UOP if they wanted to continue working in the new public institution. During this process, they were turned into applicants and continuation of their employment was conditional upon reappointment, with the burden of proof shifted to the applicant, who had to demonstrate suitability for the vacant post. The officers underwent verification in terms of their individual capacity and integrity, moral attitude, skills, and psychophysical state. A negative opinion of the commission meant it was impossible for the person to be re-employed and involved the dispersed sanction in the form of difficulties in re-employment, even in another profession $^{34}$. However, obtaining a positive assessment did not guarantee employment either, because as a result of the institutional reform, the number of posts was reduced by $80 \%$, due to change in the nature of the institution, including elimination of tasks typical for the secret political police. Moreover, people who had not performed the service could apply for employment, taking the places of previous employees as a result.

\section{2009 Uniformed Services Pensions Amendment Act}

Pension rights constitute an important element of the legal and social status of officers of uniformed and special formations as well as professional soldiers. Due to the particularity of social risk, the legislator ${ }^{36}$ included them in a separate pension system. Pursuant

29 M. Krotoszyński, Modele..., p. 115.

30 The SB was a secret police force established in the Polish People's Republic in 1956 as a successor to the repressive Ministry of Public Security (UB). The SB was the chief foreign and domestic security organization in Poland from 1956 until the fall of communism in 1989. This political police was patterned on the Soviet KGB and had its counterparts in other communist countries, such as STASI in East Germany or Securitate in Romania.

31 Ustawa z 6.04.1990 r. o Urzędzie Ochrony Państwa (Dz. U. z 1990 r. Nr 30, poz. 180).

32 B. Banaszkiewicz, Rozrachunek..., p. 468.

33 Rule-of-law tools for post-conflict states. Vetting: an operational framework, 2006, p. 34.

34 M. Kowalczyk, Polska polityka ..., p. 41.

M. Krotoszyński, Modele..., p. 116.

36 In Polish jurisprudence, the legislator in a formal sense, i.e. a law-making body, such as the parliament, is distinguished from the actual legislator, understood as a person who in fact takes part in the law-making process. In this text, I use the term "legislator" in the formal sense. In fact as S. Wronkowska explained, four concepts of the legislator are distinguished in Polish jurisprudence: 1) “dogmatic legislator” understood as a State agency (e.g. parliament) 
to the 1994 Uniformed Services Pensions Act $^{37}$ and the 1993 Soldiers Pension Act ${ }^{38}$, when the officers specified in the Acts ${ }^{39}$ (especially professional soldiers, and police and state security service officers) retire, they are entitled to a retirement pension paid from the state budget. The pension is paid also if they become completely incapable for service. If they die, the pension is paid to their families. The pension assessment basis (Polish: podstawa wymiaru emerytury) is based on the officer's last salary. Until the 2009 Uniformed Services Pensions Amendment Act came into force, the pension of the officers who were in service before 2 January 1999 was calculated as the sum of: 1) $40 \%$ of the assessment basis and 2) $2.6 \%$ of the assessment basis for each year above 15 years of service. Because both the salary and the said coefficients were higher than those of other citizens, the pension calculated this way was usually higher than in the general pension system ${ }^{40}$.

As a result of a turbulent parliamentary debate at the Polish $\mathrm{Sejm}^{41}$, an act reducing the pension of former members of the Military Council of National Salvation (Polish: Wojskowa Rada Ocalenia Narodowego, WRON) and former officers of the SB was adopted. The WRON was a kind of a military junta administering the PRL during the period of the martial law in Poland, that is, between 13 December 1981 and 22 July 1983, when the government of the Polish People's Republic drastically restricted normal life in an attempt to throttle political opposition. In both cases (WRON members and SB officers), the said $40 \%$ coefficient was eliminated and substituted only by the coefficient for each year of service, which additionally was reduced from $2.6 \%$ to $0.7 \%{ }^{42}$. In the case of WRON members, a new basis would be adopted for each year of service in the Polish Army after 8 May 1945, and in the case of former SB officers, for each year of

authorized by the norms of given system to carry out legislative activities; 2) "real legislator" understood as "a person who in fact takes part in the law making process"; 3) "institutional legislator" understood as "an institutional collective body endowed by the norms of a given system with the power to make legislative decisions or to participate in preparations to such decisions"; and 4) "rational legislator" understood as "the ideal type of the rational lawmaker which is characterized by the assumptions of a given model theory". See: S. Wronkowska, The Rational Legislator as a Model for the Real Lawmaker, in: Z. Ziembiński (ed.), Polish Contributions to the Theory and Philosophy of Law, Amsterdam 1987, pp. 148-149.

37 Act of 18 February 1994 on Retirement Provision of Officers of the Police, the Internal Security Agency, the Foreign Intelligence Agency, the Military Counterintelligence Service, the Military Intelligence Service, the Central AntiCorruption Bureau, the Border Guard, the State Protection Service, the State Fire Service, the Customs and Treasury Service, the Prison Service and Their Families (Polish title: Ustawa z 18.02.1994 r. o zaopatrzeniu emerytalnym funkcjonariuszy Policji, Agencji Bezpieczeństwa Wewnętrznego, Agencji Wywiadu, Służby Kontrwywiadu Wojskowego, Służby Wywiadu Wojskowego, Centralnego Biura Antykorupcyjnego, Straży Granicznej, Służby Ochrony Państwa, Państwowej Straży Pożarnej, Służby Celno-Skarbowej i Służby Więziennej oraz ich rodzin, Dz. U. z 1994 r. Nr 53, poz. 214 ze zm.). Both Acts (2009 and 2016) contained amendments to it.

38 Act of 10 December 1993 on Retirement Provision of Professional Soldiers and Their Families (Polish title: Ustawa z 10.12.1993 r. o zaopatrzeniu emerytalnym żołnierzy zawodowych oraz ich rodzin, Dz. U. z 1994 r. Nr 10 , poz. 36 ze zm.), which was amended only by the 2009 Act.

39 Despite the existence of separate regulations for soldiers and officers and the creation of separate systems for them, the calculation of pensions is based on similar principles and in fact could be regulated in a single statute and done in a single system.

40 See: judgment of the Constitutional Tribunal (CT) of 24 February 2010 (K 6/09), OTK-A 2010/2, item 15, points 7.5-7.7.

41 The adoption of the bill preceded the rejection of an earlier, similar project on this matter by a then opposition party Law and Justice (Polish: Prawo i Sprawiedliwość, PiS). In response to this bill, the ruling parliamentary coalition of the Civic Platform (Polish: Platforma Obywatelska, PO) and the Polish People's Party (Polish: Polskie Stronnictwo Ludowe, PSL) adopted their own bill. Both factions competed in the law-making process in order to distance themselves from the previous system.

42 This applied to the amount of pension calculated exclusively in respect to the period of service directly mentioned in the Act. The amount would normally be lower than the one which included $40 \%$ of the basis of assessment. This interpretation was confirmed by the Polish Supreme Court. See: resolution of the Supreme Court of 3 March 2011 (II UZP 2/11), OSNP 2011/15-16, item 210. 
service. The new amount of benefits was determined in the form of an administrative decision of the pension authority, which could be appealed before a court.

This regulation was challenged in full before the Constitutional Tribunal. In its ruling $^{43}$, sitting as the full panel of 15 justices, with six dissenting opinions (votum separatum), the CT adjudicated that this regulation was consistent with the Polish Constitution ${ }^{44}$. The Tribunal found the law to be in accordance with the principle of proportionality, because despite the reduction, the pensions received by those affected by this Act were still higher than the average pension paid under the general pension system $^{45}$. In addition, the CT pointed out that the reduced privileges were unjustly acquired and their abolition was predictable and in line with the principle of social justice. The Constitutional Tribunal emphasized that the positive result of the reappointment process from 1990 could not be considered a guarantee of the invariability of rights to benefits. The CT also indicated that the 2009 Act was, in its principle, compatible with the principle of social equality, the only exception being the reduction of pensions for members of the WRON for the period until the introduction of martial law in Poland, which the Tribunal considered as arbitrary, due to lack of any features that distinguished these persons in that period from others members of the Polish People's Army.

The case eventually went to the European Court of Human Rights (ECtHR), which in its judgment ${ }^{46}$ found the law to be consistent with the principle of the protection of property rights enshrined in Article 1 of Protocol No. 1 to the Convention for the Protection of Human Rights and Fundamental Freedoms ${ }^{47}$. The Court rejected the applications of 1,628 functionaries of the former State security services as inadmissible. The ECtHR confirmed that the measures of the Polish legislator could not be considered as impairing the essence of applicants' pension rights and were the end to unjustified privileges granted for political reasons. Persons who held those privileges could not have legitimate expectations that their privileged position would be maintained after transition to the democratic system ${ }^{48}$.

\section{2016 Uniformed Services Pensions Amendment Act}

After the former opposition party, Law and Justice (Polish: Prawo i Sprawiedliwość, PiS) had come to power, the Sejm adopted in December 2016 the second Uniformed Services Pensions Amendment Act. Its most important decision was to reduce the pension of SB officers assessment basis from $0.7 \%$ (provided for in the 2009) to $0 \%$ for each year of "service to a totalitarian state". In comparison to the 2009 Uniformed Services Pensions Amendment Act, the legislator significantly extended the list of

43 Judgment of the CT of 24 February 2010 (K 6/09).

44 Constitution of the Republic of Poland of 2 April 1997 (Polish title: Konstytucja Rzeczypospolitej Polskiej z 2.04.1997 r., Dz. U. Nr 78, poz. 483 ze zm.).

45 The CT pointed out that this reduction concerned only officers who were in service before 2 January 1999 and who had been employed for at least 15 years. Other elements pertinent to the calculation of pensions remained unchanged, including: 1) the right to a pension after 15 years of service, 2) advantageous calculation of the pension assessment basis in comparison to the general pension system, 3) rules and terms regarding indexation, disability and survivor pensions benefits, 4) special allowances and 5) increases in pensions (see: judgment of the CT of 24 February 2010 (K 6/09), par. 8.5).

46 Decision of the ECtHR of 14 May 2003, Cichopek and Others v. Poland (15189/10).

47 Protocol No. 1 to the Convention for the Protection of Human Rights and Fundamental Freedoms, adopted on 20 March 1952.

48 See also: M. Krotoszyński, Modele..., p. 117, fn. 153. 
persons who were subjects to the reduction, including those who had been employed in purely administrative institutions like the National Identification Number Department (Departament PESEL) or the Office for Registration of Foreigners. The years of employment in the bodies listed in the Act will not count towards the basis for calculating pensions. The final amount of pension cannot be lower than the lowest pension in the general pension system. Yet, the mere fact of service, regardless of its duration, means that the amount of the pension received cannot be higher than the average one. Moreover, the pension reduction also entails a corresponding cut in disability pension and survivor's pension after such persons.

The justification for the Act was the need to "fully abolish retirement privileges related to work in the security apparatus of the People's Republic of Poland", which was also the principle of the 2009 Uniformed Services Pensions Amendment Act, but according to the rulers, it did not achieve the intended goals, and its solutions were not fully effective ${ }^{49}$.

New solutions are characterized by a low degree of individualization of responsibility. It is possible to request the Minister of the Interior to exclude the application of the Act in some justified cases, including due to a short period of service before 31 July 1990 and remarkable service after 1989. As Krotoszyński shows, this option were barely adopted: by December 2019, 2,143 out of 4,869 applications had been decided and only 38 approved ${ }^{50}$. An additional possible exclusion can be provided if the persons concerned can prove that before 1990, without the knowledge of superiors, they established cooperation with and actively supported persons or organizations working for the independence of the Polish State. However, the burden of proof is shifted to persons whose pensions are subject to the reduction, and the Minister is given extensive and discretionary powers.

At this point, apart from questions about the fairness of the Uniformed Services Pensions Amendment Acts of 2009 and 2016, this process raises a number of legal doubts $^{51}$. The 2016 Amendment only affected officers and excluded professional soldiers, even though they are covered by a similar pension system. Therefore, the legislator put this group in a much worse legal situation, compared to the general pension system and to those former officers who did not undergo the reappointment process in $1990^{52}$. Although the law provides for the possibility of excluding the application of the provisions, the imprecise mechanism and the Minister's discretion testify to their

49 Helsinki Foundation for Human Rights Opinion, 2292/2016/MPL/BGM, 13.12.2016, http://www.hfhr.pl/wp-content/ uploads/2016/12/HFPC_opinia_13122016.pdf, accessed on: 7 April 2020.

50 M. Krotoszyński, Transitional Justice and Constitutional ..., p. 5, fn. 14.

51 The law was criticized by the courts. See e.g.: judgments of Częstochowa District Court [Polish: Sąd Okręgowy $w$ Częstochowie] of 31 May 2019 (IV U 241/19, LEX No. 2704111) and of 20 September 2019 (IV U 1195/19, LEX No. 2747474 and IV U 826/19, LEX No. 2729356). In addition, the Warsaw District Court (Polish: Sąd Okregowy $w$ Warszawie) twice referred the law to the CT to verify constitutionality of some of its provisions. Both cases (P 4/18, $\mathrm{K} 8 / 18$ ) are pending. An interesting view on the matter is shown by the positions of the parties to these proceedings. For example, the Polish Sejm and the Minister of Justice clearly support the constitutionality of the 2016 Amendment. Case information available at: https://ipo.trybunal.gov.pl/ipo/Sprawa?cid=2\&sprawa=20992 (K 8/18) and https://ipo. trybunal.gov.pl/ipo/ Sprawa?cid=2\&sprawa=20215 (P 4/18), accessed on: 7 April 2020.

52 As mentioned above, not all uniformed services officers had taken part in the reappointment process, which was voluntary. Those have switched pension system to the general one and have no right to officers' pension. That is why the reduction of pensions does not apply to them (see e.g.: B. Wiktorowska, Byli esbecy, którzy przeszli do ZUS, maja się świetnie [Eng. Former SB Officers Who Are in the General Pension System Are Doing Great], "Dziennik Gazeta Prawna", 10 October 2019, https://praca.gazetaprawna.pl/artykuly/1434223, funkcjonariusze-sluzby-bezpieczenstwaustawa-dezubekizacyjna.html, accessed on: 7 April 2020). 
uncertainty ${ }^{53}$. What is more, this law is already the third time that communist secret service officers are targeted by transitional justice measures. This is doubtful from both a legal point of view, as it compromises the citizens' trust in the state, and from a historical perspective. It ascribes to each individual in any way associated with these organizations (even only as an administrative worker) the guilt of being complicit in "the consolidation of the inhumane system of power".

\section{Reducing pensions as part of politics of memory}

Therefore, two issues should be distinguished. Firstly, is decreasing pension benefits of Uniformed Services officers acceptable? Secondly, if the answer is affirmative, should the methods used to reduce these pensions be considered admissible in a democratic state ruled by law? It seems that the mere reduction of benefits is permissible from the perspective of the rule of law, however, it should be subject to detailed regulation regarding the principles and the trial itself, to guarantee protection of these persons' procedural rights.

Reducing pensions has, in fact, two goals: the retrospective one and the prospective one. The retrospective goal is about administering historical justice by penalizing a specific group of people using various mechanisms (in this case administrative sanctions). In the prospective aspect, this is an element of institutionalizing memory and building a specific political narrative.

The legislator indicated that the main purpose of the laws in question was to "restore historical justice". This emphasizes the retrospective nature of these laws: to some extent, they aim to bring redress to victims. This is one of the transitional justice mechanisms used during the transformation period or immediately after it, but in relation to a specific group: the former members of uniformed services. However, the content of the regulation itself, as well as the entire narrative accompanying its introduction, indicates that the acts reducing pensions are an exemplification of the legal institutionalization of collective memory. The group, which has already been subject to transitional justice measures in the form of vetting, is facing ever more sanctions due to the promotion of a specific narrative about the past. The purpose of these regulations is not to discharge the tasks posed by transitional justice, but rather to instrumentalize its mechanisms. The legislator uses them to conduct political dispute and arouse heightened social emotions, which are to increase support for the solutions themselves and, consequently, for those who introduced them.

What supports this argument is the fact that the reduction of pension was introduced many years ( 20 and 27 years respectively) after the political transformation. Employing the mechanisms of transitional justice many years after the transition indicates the need to consolidate the political system and to create a specific narrative on the political scene. Thus, they are to a lesser extent a result of the actual need for reckoning expressed by organized groups of victims.

The fact that multiple transitional justice mechanism have been used against the same group also breaches the citizens' trust in the state. The year 1990 brought sanctions

\footnotetext{
53 See: M. Czechowski, Zaopatrzenie emerytalne funkcjonariuszy formacji umundurowanych $i$ specjalnych $w$ świetle tzw. ustawy dezubekizacyjnej z $2016 r$. Wybrane zagadnienia [Eng. Pension Provision of Officers from Uniformed and Special Services in the Light of the Altering Act of 16 December 2016. Selected Issues], "Praca i Zabezpieczenie Społeczne" 2018/9, pp. 35-39.
} 
against former SB employees in the form of dismissal and subsequent verification as part of the re-employment procedure. All those who were negatively vetted were prevented from returning to work and often met with a dispersed sanction as well. One can agree that both clarification and retribution already took place at that time. Nineteen years after the verification related the disbandment of the SB, administrative sanctions were applied in the form of a reduction of pension for this group. This was certainly an element of the legal institutionalization of collective memory and it had its roots in the context of transitional justice. However, as the legislator resorts to this type of sanction again (26 years after the said verification) by introducing the 2016 Act, one can assume that one of its primary goals was to create a specific narrative about the past.

Both acts raise a number of doubts. Former officers, positively verified and reemployed in reappointment process in a democratic state, retiring after the 1994 Uniformed Services Pensions Act came into force, acquired the right to pension based on the provisions of the Act already established by the authorities of the Republic of Poland. Lowering pensions using the new provisions shows a kind of collectivization of responsibility supported by a "presumption of guilt" ${ }^{4}$, because the burden of proof was shifted from the state to the citizen who had to prove his or her innocence in order to restore the previous level of pension. The simplifications contained in both Amendments, as well as a specific narrative in the media often led to unjust stigmatization ${ }^{55}$. The charges brought collectively against the whole group "have a strong moral, emotional and legal condemnation" $" 56$, which influences the fact that in the mass media the law was referred to as an act of dezubekizacja ${ }^{57}$, defined as an element of decommunization in Poland, aimed at depriving former SB officers of any privileges.

However, one should ask whether this type of statement by the legislator is consistent with reality. The members of government also referred as $u b e k^{58}$ to those who did not play any active role in consolidating the "inhumane system of power" 59 . The Act treats as synonymous two different concepts: officer of uniformed services and officer as a person working in state administration ${ }^{60}$. In turn, the notion of "consolidating the inhumane system of power" can be applied to people employed in the political police, but not necessarily to those whose function was not of an operational nature. Would it be fair, then, to treat such people in the same way as those who really served to consolidate the system, e.g. during Stalinism?

Undoubtedly, the argument for using administrative sanctions in general is to protect state institutions from people who are not loyal to the new order. This is done to

${ }^{54}$ See: dissenting opinion of Judge Adam Jamróz to judgment of the CT of 24 February 2010 (K 6/09), par. I in fine.

55 See: Dissenting opinion of Judge Ewa Lętowska to judgment of the CT of 24 February 2010 (K 6/09), paras. 1-24.

56 Dissenting opinion of Judge Ewa Łętowska..., paras. 11-12.

57 Dissenting opinion of Judge Ewa Łętowska..., par. 12. This piece of legislation is colloquially and contemptuously referred to as ustawa dezubekizacyjna. Dezubekizacja is a non-normative term formed from the term ubek: a colloquial and pejorative term describing an officer of the communist Security Office (Urzad Bezpieczeńśtwa, UB), and later also an officer of the SB. In this sense dezubekizacja is part of decommunization sensu largo. Both terms - ubek and ustawa desubekizacyjna - are insulting.

58 Although the legislator does not use terms ubek and ustawa deubekizacyjna, in the public debate the representatives of the government used them frequently. See e.g.: Szydto przeciw wysokim emeryturom dla bytych funkcjonariuszy $S B$ [Eng. Szydto against High Pensions for Former SB Officers], polsatnews.pl, 24 November 2016, https://www.polsatnews. $\mathrm{pl} /$ wiadomosc/2016-11-24/szydlo-przeciw-wysokim-emeryturom-dla-bylych-funkcjonariuszy-sb/, accessed on: 7 April 2020. This was aimed at giving some axiological justification of the provisions of the Act. The mere use of these terms is a kind of instrumentalization of memory.

59 M. Kowalski, Polska polityka..., p. 45.

60 Dissenting opinion of Judge Ewa Lętowska..., paras. 14-15. 
protect democracy, sovereignty, and the rights of individuals (prospective goal), as well as to satisfy the sense of social justice. Reducing pensions relates primarily to the last factor: it can hardly be said to protect democracy. However, another question arises - were people employed in the services in the last years (after 1986) of the Polish People's Republic capable of perpetuating the inhumane system of power, when it was falling into decline and numerous reforms were carried out? The legislator did not answer the above questions, which is why those acts contain so many simplifications and elements that can be associated with politics of memory, and not the desire to settle accounts or to administer historical justice. Therefore, the law aims primarily to create a coherent narrative and to serve the interests of its creators.

After the political transformation in Poland, the view that the PRL was a communist-totalitarian state throughout the whole period of its existence became the one true view of the country's past. Symbolically, after transition, authorities turned to the period before World War II, reducing the period of the PRL to a kind of a black hole in the history of the state and nation, without debating whether the PRL was in all its aspects a communist state ${ }^{61}$. In fact, negation of the previous system was made the foundation of democracy building ${ }^{62}$. This negation is also visible in both Acts, which create collective memory through the use of terms such as "communism" or "totalitarian state". The associations with these terms are much more negative than for example with "socialism" or even "authoritarianism". The use of such pejorative emotional language supports the argument that the aim of the law is to obtain social approval and to create a specific vision of the past. The careful choice of words leads to the perpetuation of subjective historical dogmas in society, shaping a vision of history not entirely proven ${ }^{63}$ and largely subordinated to the political narrative of the given group ${ }^{64}$. Subsequently, the law causes society to move away from history in favour of memory, from shaping factual awareness in favour of disputes over preferred narratives.

As a result the belief about the demonic nature of the PRL is spreading. The conviction is also growing that people connected with the previous system are pursuing foreign interests and that if anyone has ever been a "communist", they do not cease to be one even when they fully accept the new system and serve its construction or functioning. Therefore, a zero-one narrative of the past is imposed, without considering the complexity of history. As a result, in political discourse, anti-communism becomes a crucial factor when it comes to the Polish identity, sometimes more important than the principles of liberal democracy.

Thus, the legal means for reducing officers' pensions and the arguments which justify them create certain myths in the name of the nation's integrity, while rejecting other

61 A. Walicki, W Polsce nie byto komunizmu [Eng. There Was No Communism in Poland], interviewed by K. Pilawski, “Tygodnik Przegląd”, 2 December 2013, https://www.tygodnikprzeglad.pl/polsce-nie-bylo-komunizmu/, accessed on: 7 April 2020.

62 A. Walicki, $W$ Polsce...

${ }_{63}$ One can notice a constant dispute in the literature about whether Poland in 1945-1989 was a totalitarian and communist state or an authoritarian and socialist one. The multitude of publications and their content indicates that this is a very complex issue. See e.g.: R. Bäcker, PRL między totalitaryzmem a autorytaryzmem [Eng. PRL between Totalitarianism and Authoritarianism], in: A. Kasińska-Metryka (ed.), Polska $w$ dobie przemian [Eng. Poland in the Era of Change], Kielce 2004; A. Walicki, Polskie zmagania z wolnościa. Widziane z boku [Eng. Polish Struggles with Freedom. Seen from the Side], Kraków 2000. Lech Mażewski even uses the term "post-totalitarian authoritarianism" to describe the period between 1956 and 1989 in Poland in: L. Mażewski, Posttotalitarny autorytaryzm PRL 1956-1989 [Eng. Post-totalitarian Authoritarianism in the PRL 1956-1989], Warszawa-Biała Podlaska 2010.

${ }_{64}$ M. Kowalczyk, Polska polityka ..., p. 53. 
competing historical traditions. The politics of memory in this formula aims to unite the nation not so much by a common history as by common views on the past. To this end, accountability mechanisms are used, which, as can be seen, show great potential in the field of community formation and utility in political struggle. Thus, the reduction of officers' pensions can be seen as an instrument of a change of the country's political status, its political basis, and its axiological and symbolic universe. The above-mentioned laws have become tools for heritage creation and memory control. In this case, the legal institutionalization of memory means the formalization of social transformations and is the result of a desire to stabilize and preserve a particular order. Based on national and anti-communist foundations, the laws "bringing justice" to specific groups associated with the previous system play a key role in creating a dominant ideological message, and thus, the collective memory of society. Decommunization becomes a reason for legitimizing government policies, a sure sign of ideological continuity, or even a visualization of the myth of a given group.

\section{Conclusions}

In the course of political changes that followed the fall of communism in Poland, ideological reassessments were made, which triggered the process of reviewing social beliefs and ideas about the past. Currently the state uses many forms of institutionalization of memory, which permeates all spheres of cultural reality and becomes the axis of many practices, the medium of social imaginations, and often a catalyst of change. Collective memory is used as a reservoir of social order and a factor of its stability, justifying the retroactive orientation of identity policy and affirming a specific vision of the past.

In shaping collective memory, authorities use various methods, including legislation. From this perspective, the Acts discussed above are a means of shaping a specific historical awareness, constituting a legal institutionalization of memory. This can lead to an instrumental treatment of history and to using it to pursue specific political interests. History can become a tool in the form of moral stories about the past, serving to shape a specific vision of past events through the selection of historical facts. This leads to a kind of selectivity and flattening of historical events for the needs of current political discourse. Such a phenomenon can be seen in the Uniformed Services Pensions Amendment Acts of 2009 and 2016, as presented in this paper. They are used to shape specific and explicit views about the past system and people associated with it, while using this discourse as an element of political dispute. Whether using law in this manner is moral, must be left to individual evaluation.

\section{Uniformed Services Pension Amendment Acts in Poland as Part of State Politics of Memory}

\footnotetext{
Abstract: The article is an analysis of the regulations regarding the reduction of pensions of former officers of the People's Republic of Poland's security services as an element of state politics of memory, presenting the Uniformed Services Pension Amendment Acts of 2009 and 2016 from the perspective of transitional justice.

Whilst investigating the admissibility of using such a retribution mechanism, the author draws attention to the purpose of this type of regulation. Reducing pensions has, in fact,
} 
two goals - a retrospective one and a prospective one. The retrospective goal is about administering historical justice by penalizing a specific group of people using various mechanisms (in this case administrative sanctions). In the prospective aspect, it is an element of institutionalizing memory and building a specific political narrative. As a consequence, apart from commemorative practices, it aims to produce and disseminate knowledge in public space, while clearly rejecting the past regime.

In relation to the Uniformed Services Pension Amendment Acts, while the Act of 2009 was to some extent aimed at the retrospective goal, the 2016 Act is primarily an element of politics of memory used by authorities to control the recollection of past events by explicitly condemning the previous system and all persons in any way related to it. For this reason, the author focuses on the mechanism of reducing pensions as one of the elements of politics of memory in Poland.

Keywords: Uniformed Services Pension Amendment Acts in Poland, politics of memory, institutionalization of collective memory, decommunization, reducing pensions of communist officials, transitional justice 


\section{BIBLIOGRAFIA / REFERENCES:}

Banaszkiewicz, B. (2003). Rozrachunek z przeszłością komunistyczną w polskim ustawodawstwie i orzecznictwie Trybunału Konstytucyjnego. Ius et Lex 1, 441-486.

Bäcker, R. (2004). PRL między totalitaryzmem a autorytaryzmem. In A. Kasińska-Metryka (Ed.), Polska w dobie przemian. Kielce: Wydawnictwo Akademii Świętokrzyskiej.

Bevir, M. (1994). Objectivity in History. History and Theory 3, 328-344.

Blake, Ch. (1955). Can History Be Objective? Mind 64, 61-78.

Czarnota, A. (2007). The Politics of the Lustration Law in Poland, 1989-2006. In A. Mayer-Rieckh, P. de Greiff (Eds.), Justice as Prevention. Vetting Public Employees in Transitional Societies. New York: Social Science Research Council, 222-258.

Czarnota, A. (2009). Lustration, Decommunization and the Rule of Law. Hague Journal on the Rule of Law 1, 307-336.

Czechowski, M. (2018). Zaopatrzenie emerytalne funkcjonariuszy formacji umundurowanych i specjalnych w świetle tzw. Ustawy dezubekizacyjnej z 2016 r. Wybrane zagadnienia. Praca $i$ Zabezpieczenie Społeczne 9, 35-39.

Elser, J. (2004). Closing the Books: Transitional Justice in Historical Perspective. Cambridge: Cambridge University Press.

Hinshaw, V. (1958). The Objectivity of History. Philosophy of Science 1, 51-58.

Huntington, S. (1991). The Third Wave: Democratization in the Late Twentieth Century. Norman: University of Oklahoma Press.

Jelin, E. (2007). Public Memorialization in Perspective: Truth, Justice and Memory of Past Repression in the Southern Cone of South America. The International Journal of Transitional Justice 1, 138156.

Kaminski, M.M., Nalepa, M., O’Neill, B. (2006). Normative and Strategic Aspects of Transitional Justice. The Journal of Conflict Resolution 3, 295-302.

Kowalczyk, M. (2019). Polska polityka historyczna w ustawach dekomunizacyjnych i dezubekizacyjnych. Sensus Historiae 3, 35-55.

Kritz, N.J. (Ed.). (1995). Transitional Justice: How Emerging Democracies Reckon with Former Regime. Vol. I-III. Washington: United States Institute of Peace.

Krotoszyński, M. (2016). The Transitional Justice Models and the Justifications of Means of Dealing with the Past. Oñati Socio-legal Series 3, 584-606.

Krotoszyński, M. (2017). Modele sprawiedliwości tranzycyjnej. Poznań: Wydawnictwo Naukowe UAM.

Krotoszyński, M. (2019), Transitional Justice and the Constitutional Crisis: The Case of Poland (20152019). Archiwum Filozofii Prawa i Filozofii Społecznej 3, 22-39.

Mażewski, L. (2010). Posttotalitarny autorytaryzm PRL 1956-1989. Biała Podlaska: Arte.

Nalepa, M., Krotoszyński, M. (forthcoming). Poland. In L. Stan, N. Nedelsky (Eds.), Encyclopedia of Transitional Justice. Vol. 2, 2nd ed. Cambridge: Cambridge University Press.

Nowak, L. (1991). Power and Civil Society: Toward a Dynamic Theory of Real Socialism. New York: Praeger. 
Ross, A. (2004). Truth and consequences in Guatemala. GeoJournal 1, 73-79.

Rumin, S. (2007). Gathering and Managing Information in Vetting Processes. In A. Mayer-Rieckh, P. de Greiff (Eds.), Justice as Prevention. Vetting Public Employees in Transitional Societies. New York: Social Science Research Council.

Safjan, M. (2007). Transitional Justice: The Polish Example, the Case of Lustration. European Journal of Legal Studies 2, 235-253.

Schacter, D.L. (2003). Siedem grzechów pamięci: jak zapominamy i zapamiętujemy. Warszawa: PWN.

Severin, A. (1996). Measures to dismantle the heritage of former communist totalitarian systems (Doc. 7568). Council of Europe's Parliamentary Assembly's Committee on Legal Affairs and Human Rights.

Szacka, B. (2006). Czas przeszły: Pamięć-Mit. Warszawa: Scholar.

Teitel, R. (2000). Transitional Justice. New York: Oxford University Press.

Teitel, R. (2003). Transitional Justice Genealogy. Harvard Human Rights Journal 16, 69-94.

Walicki, A. (2013). W Polsce nie było komunizmu. Interviewed by K. Pilawski. Tygodnik Przeglad. 2 December 2013. Retrieved from: https://www.tygodnikprzeglad.pl/polsce-nie-bylo-komunizmu/.

Walicki, A. (2000). Polskie zmagania z wolnością. Widziane z boku. Kraków: Universitas.

Wigura, K., Kuisz, J., Sadurski, W. (Eds.) (2018). Trudne rozliczenia z przeszłościa, Tom I: Sprawiedliwość okresu przejściowego w perspektywie międzynarodowej. Warszawa: Scholar.

Wigura, K., Kuisz, J., Sadurski, W. (Eds.) (2018). Trudne rozliczenia z przeszłościa, Tom II: Polska w Perspektywie Europy Środkowo-Wschodniej. Warszawa: Scholar.

Williams, M.S., Nagy, R., Elster, J. (Ed.) (2012). Transitional Justice. New York: New York University Press.

Wolff-Powęska, A. (2010). Pamięć - brzemię i uwolnienie. Niemcy wobec nazistowskiej przeszłości (1945 - 2010). Poznań: Zysk i S-ka.

Wronkowska, S. (1987). The Rational Legislator as a Model for the Real Lawmaker. In Ziembiński, Z. (Ed.), Polish Contributions to the Theory and Philosophy of Law. Amsterdam: Rodopi.

Wronkowska, S., Ziembiński, Z. (2001). Zarys teorii prawa. Poznań: Ars boni et aequi. 